\title{
Construction of hybrid $x y l E$ genes between the two duplicate homologous genes from TOL plasmid pWW53: comparison of the kinetic properties of the gene products
}

\author{
Peter A. Williams, * Susan J. Assinder and Linda E. Shaw \\ School of Biological Sciences, University of Wales, Bangor, Gwynedd LL57 2UW, UK
}

(Received 6 March 1990; revised 10 April 1990; accepted 25 April 1990)

\begin{abstract}
The two $x y l E$ genes for catechol 2,3-oxygenase, encoded by TOL plasmid pWW53, carry a common SalI restriction site within the reading frame. Each gene was cut at the $\mathrm{SaI}$ site and the $5^{\prime}$ end of each gene spliced to the 3 ' end of the other to form hybrid genes, from both of which catalytically active catechol 2,3-oxygenase activities were expressed. The kinetic parameters were determined for the gene products of both the hybrid and the wild-type $x y l E$ genes with catechol, 3-methylcatechol and 4-methylcatechol as substrates. Comparison of the results suggested firstly, that the $\mathbf{C}$-terminal regions of the enzymes determined both the binding and the catalytic specificity, and, secondly, that the $\mathbf{N}$-terminal region of one of the enzymic gene products contained a secondary binding site which caused inhibition by excess substrate for methylcatechol substrates but not for catechol. One of the wild-type enzymes appeared to have an intrinsically higher activity for all three substrates than the other. This higher activity depended on the presence of both its $\mathrm{C}$ - and $\mathrm{N}$-terminal regions, and in both hybrid enzymes, which contained only one of these regions, activity was significantly reduced.
\end{abstract}

\section{Introduction}

Osborne et al. (1988) described the occurrence on TOL catabolic plasmid pWW53 of two separate operons for the meta pathway genes. These duplicate copies were homologous as judged by their ability to cross-hybridize and from a number of apparently similar restriction sites. Both copies were fully functional and could support growth on $m$-toluate when individually ligated into a vector plasmid and transferred into a TOL-plasmid-free strain of Pseudomonas. However there was a major difference in the level of expression of their encoded enzymes, the operon located on the smaller HindIII fragment $\mathrm{HB}$ producing only about $10 \%$ of the specific activity produced by the operon found on HindIII fragment HA. The results could not distinguish whether this was the result of a difference in their regulatory mechanisms or due to intrinsically lower enzyme activities.

A comparison of the restriction maps for the regions carrying the two $x y l E$ genes (encoding catechol 2,3oxygenase; $\mathrm{C} 23 \mathrm{O}$ ) showed that within the centre of each coding region there is an apparently common SalI site (Osborne et al., 1988). This paper describes the forma-

Abbreviation: C23O, catechol 2,3-oxygenase. tion of two hybrid genes using this restriction site to ligate the $5^{\prime}$ end of each to the $3^{\prime}$ end of the other. The resulting genes both produced active gene products, showing that the two $S a I I$ sites lie at identical locations within the genes. The kinetic properties of the two wildtype and two hybrid $\mathrm{C} 23 \mathrm{O}$ s have been compared to ascertain whether any catalytic property can be assigned to either the $\mathrm{N}$ - or $\mathrm{C}$-terminal regions of the proteins.

\section{Methods}

Bacterial strains and plasmids. Plasmids used and constructed in this work are shown in Table 1. The hosts for all experiments were Escherichia coli strains ED8654 or JM103.

Media and culture conditions. For enzyme assays, strains were grown on Luria broth and cell extracts prepared by sonication as described by Cane \& Williams (1982).

Assay of catechol 2,3-oxygenase, and kinetic analysis. The activity of C23O was determined in cell extracts by the basic procedure of SalaTrepat \& Evans (1971). For the determination of kinetic constants, a range of about 15 concentrations of catechol and methylcatechol substrates from about $33 \mu \mathrm{M}$ to about $2 \mathrm{mM}$ were used in the standard assay mixture. The absolute concentrations of the stock solutions of substrates used to make up the individual reactions were determined by complete conversion to the ring-fission products by excess cell extract of $E$. coli strains carrying the cloned $x y l E$ gene on a high expression vector. 
Table 1. Plasmids

\begin{tabular}{|c|c|}
\hline Plasmid name & Notes \\
\hline \multicolumn{2}{|l|}{ Vectors } \\
\hline pFB69 & Barany (1985) \\
\hline pBR325 & Prentki \& Kirsch (1982) \\
\hline pUC18 & Yanisch-Perron et al. (1985) \\
\hline pKT230 & Bagdasarian et al. (1981) \\
\hline \multicolumn{2}{|r|}{ 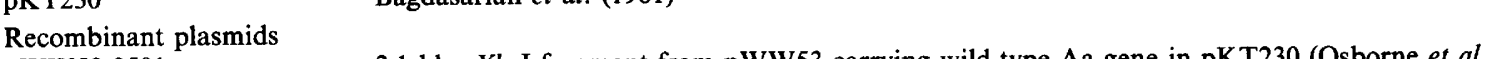 } \\
\hline & 1988) \\
\hline pWW53-3502 & $\begin{array}{l}2 \cdot 1 \mathrm{kbp} \text { XhoI fragment from pWW53 carrying wild-type Bb gene in pKT230 (Osborne et al., } \\
1988 \text { ) }\end{array}$ \\
\hline pWW53-3511 & $\begin{array}{l}2 \cdot 1 \mathrm{kbp} X \text { XhoI fragment from pWW } 53 \text { carrying Aa gene cloned into the SalI site of pUC18 (this } \\
\text { study) }\end{array}$ \\
\hline pWW53-3515 & $\begin{array}{l}2 \cdot 1 \mathrm{kbp} X \text { XhoI fragment from pWW } 53 \text { carrying Bb gene cloned into the } S a I \text { site of pUC18 (this } \\
\text { study) }\end{array}$ \\
\hline pWW53-5000 & $1.76 \mathrm{kbp}$ partial SalI fragment from pWW53-3511 inserted into XhoI site of pKT230 (this study) \\
\hline pWW53-5100 & $0.55 \mathrm{kbp}$ Sall fragment from pWW53-3501 in pBR325 (this study) \\
\hline pWW $53-6000$ & $1.76 \mathrm{kbp}$ partial Sall fragment from pWW53-3515 inserted into $X$ hoI site of pKT230 (this study) \\
\hline pWW53-6100 & $0.55 \mathrm{kbp}$ Sall fragment from pWW53-3502 in pBR325 (this study) \\
\hline pWW53-5500 & $\begin{array}{l}0.65 \mathrm{kbp} \text { Sall } / \text { Xhol fragment of pFB69 inserted into the unique } S a l l \text { site of pWW53-5000 (this } \\
\text { study) }\end{array}$ \\
\hline pWW53-6500 & $\begin{array}{l}0.65 \mathrm{kbp} \mathrm{Sall} / X \text { hoI fragment of pFB69 inserted into the unique } S a l \mathrm{I} \text { site of pWW53-6000 (this } \\
\text { study) }\end{array}$ \\
\hline pWW53-5600 & $\begin{array}{l}0.55 \mathrm{kbp} S a l \text { fragment of pWW53-6100 inserted into the unique } S a l \text { site of } \mathrm{pWW} 53-5500 \text { to } \\
\text { form the hybrid Ab gene (this study) }\end{array}$ \\
\hline pWW53-6600 & $\begin{array}{l}0.55 \mathrm{kbp} \text { Sall fragment of pWW53-5100 inserted into the unique } S a I \text { site of pWW53-6500 to } \\
\text { form the hybrid Ba gene (this study) }\end{array}$ \\
\hline
\end{tabular}

The amounts of cell extract added were chosen to ensure that the rate of change of absorbance due to production of ring-fission product was linear over $1 \mathrm{~min}$ and no greater than $1.0 \mathrm{~min}^{-1}$. The rate of reaction was determined using the microcomputer regression analysis afforded by the Kontron spectrophotometer, based upon the first 10 absorbance measurements made at $3 \mathrm{~s}$ intervals. The molar absorption coefficients for the three products were taken as $\left(\mathrm{M}^{-1} \mathrm{~cm}^{-1}\right)$ : catechol, $36 \times 10^{3}$ at $\lambda_{\max }=375 \mathrm{~nm} ; 3$-methylcatechol, $15 \times 10^{3}$ at $\lambda_{\max }=388 \mathrm{~nm}$; and 4methylcatechol, $31.5 \times 10^{3}$ at $\lambda_{\max }=382 \mathrm{~nm}$.

The values of $K_{\mathrm{m}}$ and $V$ were calculated by non-linear regression analysis according to Wilkinson (1961) using the computer program ENZPACK3 (Williams \& Zaba, 1989). Because of substrate inhibition discovered during the course of this work, only substrate concentrations below which the effect was not apparent $(\leqslant 500 \mu \mathrm{M})$ were used in the calculation of the parameters; this was done even for enzyme/substrate combinations where there appeared to be no substrate inhibition. Routinely seven or eight rate measurements in this range were used to calculate $K_{\mathrm{m}}$ and $V$. For each enzyme/substrate combination, five or six separate determinations of the parameters were carried out, and the values quoted are the means and standard deviations of all of these results.

Plasmid and DNA manipulations. All experiments were carried out according to procedures outlined by Osborne et al. (1988)

\section{Results and Discussion}

\section{Construction of hybrid genes}

The two $x y l E$ genes were initially available on $2 \cdot 1 \mathrm{kbp}$ $X h o I$ fragments cloned into the XhoI site in pKT230.
Recombinant plasmid pWW53-3501 (Fig. 1a) carried the gene from the HA fragment of pWW53; the restriction map of its insert indicates that the gene corresponds to type 1a, as denoted by Chatfield \& Williams (1986). For convenience we will refer to this gene (and its enzyme product where applicable) as type Aa, denoting its $5^{\prime}$ end up to the $S a l I$ site, by the capital A and the $3^{\prime}$ end from the Sall site, by the lower case a. Plasmid pWW53-3502 carries the gene from the HB fragment of pWW53, which corresponds to type $1 \mathrm{~b}$ (Chatfield \& Williams, 1986) and we shall refer to this as type $\mathrm{Bb}$, using the same notation. Initially, each of the XhoI inserts of pWW53-3501 and pWW53-3502 was excised and religated into the SalI site of pUC18 to form plasmids pWW53-3511 and pWW53-3515 respectively. The hybrid Sall/XhoI sites formed at each terminus of the inserts can no longer be cut with either restriction enzyme.

Since the principles of constructing the two hybrid genes are essentially identical, we shall describe only the construction of the gene between the $5^{\prime}$ end of the $\mathrm{Aa}$ gene and the $3^{\prime}$ end of the $\mathrm{Bb}$ gene, forming the $\mathrm{Ab}$ gene. The equivalent plasmids in the formation of the $\mathrm{Ba}$ hybrid are included in Table 1.

Each $X h o I$ insert has three SalI sites, one within the $x y l E$ gene and one at either end (Fig. 1a). In order to obtain a fragment with a unique $S a I I$ site within the gene, plasmid pWW53-3511 was partially digested with SalI 
(a)

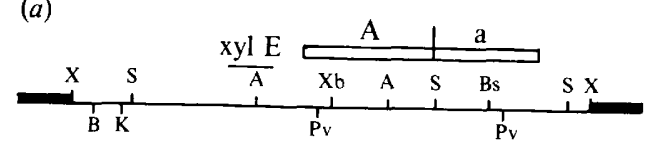

(b)

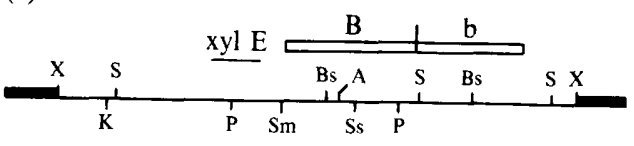

(c)

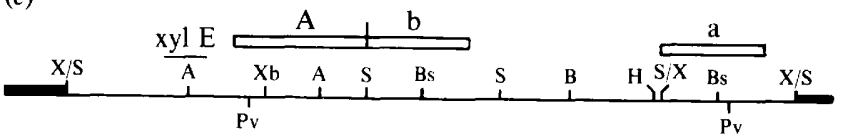

(d)

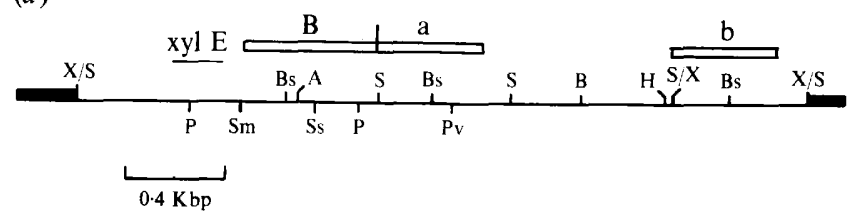

Fig. 1. Accurate restriction maps of the inserts carrying $x y l E$ genes. (a) Wild-type gene of type Aa on $2 \cdot 1 \mathrm{kbp} X$ hoI fragment in plasmids pWW53-3501 and pWW53-3511. (b) Wild-type gene of type Bb on 2.1 kbp fragment in plasmids pWW53-3502 and pWW53-3515. (Note that in pWW53-3511 and pWW53-3515 the sites at the end of the insert are X/S rather than X.) (c) Hybrid gene of Ab type on plasmid pWW535600. (d) Hybrid gene of type Ba on plasmid pWW53-6600. The inserts are denoted by the thin lines and the termini of the vector plasmids by the thick lines. The location of the $x y l E$ genes and their respective domains are shown above each map. The abbreviations for restriction sites are: A, AvaI; B, BamHI; Bs, BstEII; P, PstI ; Pv, PvuII; S, SalI; $\mathrm{X} / \mathrm{S}$, hybrid $\mathrm{Xhol} / \mathrm{Sall}$ site formed by inserting a SalI fragment into an XhoI site; Sm, SmaI; Ss, SstI; X, XhoI; Xb, XbaI.

and recloned into the $X h o \mathrm{I}$ site of pKT230 to form hybrid XhoI/SalI termini (Fig. 2). After transformation, the plates were sprayed with catechol to detect strains which had acquired a functional $\mathrm{C} 23 \mathrm{O}$ and therefore carried the intact Aa gene with the internal SalI site unaltered. The resulting plasmid from such a transformant was retained as pWW53-5000, after checking that it had the expected restriction map.

The 3' end of the $\mathrm{Bb}$ gene was isolated by digestion of pWW53-3502 with SalI and ligation into the SalI site of pBR325, forming plasmid pWW53-6100. The strategy was then to introduce the insert from this plasmid into the (now) single $\mathrm{Sal}$ site of plasmid pWW53-5000. Since this was expected to generate a functional hybrid gene, if inserted in the correct orientation, there was no selection which would enable us to distinguish between transformants which contained recircularized pWW53-5000, and therefore a functional Aa gene, and those with a functional hybrid $\mathrm{Ab}$ gene: both would produce yellow transformants after spraying with catechol.
To overcome this problem, we inserted a neutral piece of DNA into the SalI site of pWW53-5000 to inactivate the $x y l E$ gene. The fragment arbitrarily chosen for this was a $0.65 \mathrm{kbp} S a l \mathrm{I}-\mathrm{XhoI}$ fragment from plasmid pFB69. Triple $S a l \mathrm{I} / \mathrm{XhoI} / \mathrm{PstI}$ digestion of pFB69 produces three fragments, one of which is the desired neutral piece of $0.65 \mathrm{kbp}$. The triply-digested pFB69 was ligated with Sall-digested pWW53-5000 and transformants were selected which did not go yellow on spraying with catechol. Since the insert could be in two orientations, resulting recombinants were screened to ensure that the single SalI site remaining was at the $3^{\prime}$ end of the $5^{\prime}$ section (A) of the gene, as in the retained plasmid pWW53-5500 (Fig. 2).

The final stage was to insert the SalI fragment from pWW53-6100, carrying the $3^{\prime}$ end of the $\mathrm{Bb}$ gene, into the single SalI site of pWW53-5500, selecting for C23Opositive strains, which contained the hybrid $\mathrm{Ab}$ gene. The resulting plasmid, pWW53-5600 (Fig. 2) was checked for the expected configuration of restriction sites (Fig. 1c).

Plasmid pWW53-6600, carrying the hybrid Ba gene (Fig. 1d) was constructed in an exactly analogous way, starting with plasmids pWW53-3515 (Fig. $1 b$ ) and pWW53-3501 (Fig. 1a).

\section{Enzyme activity of gene products}

Using the standard assay procedure for C23O (SalaTrepat \& Evans, 1971), in which the substrate concentrations are $0.1 \mathrm{mM}$, cell extracts from $E$. coli strains carrying the wild-type and hybrid genes all contained significant activity against catechol, 3-methylcatechol and 4-methylcatechol (data not shown). The specific activity due to the $\mathrm{Bb}$ gene product was considerably lower than that due to the Aa gene product, as had been reported earlier (Osborne et al., 1988). In the strains carrying the $\mathrm{Ab}$ and $\mathrm{Ba}$ genes the specific activities were low and comparable to that carrying the $\mathrm{Bb}$ gene. The absolute activities and the relative values for the three substrates are of no significance in the light of the features revealed in the subsequent kinetic analysis.

\section{Kinetics of gene products}

Detailed kinetic analysis of the four $\mathrm{C} 23 \mathrm{O}$ enzymes in cell extracts of $E$. coli indicated a feature not previously reported for any ring-cleavage dioxygenase. Two of the enzymes ( $A a$ and $A b$ ) showed significant classical substrate inhibition with the two methylcatechols at concentrations above $0.5 \mathrm{~mm}$ but no such effect with catechol itself. A typical set of Michaelis-Menten curves is shown for enzyme Aa in Fig. 3(a). The other two 


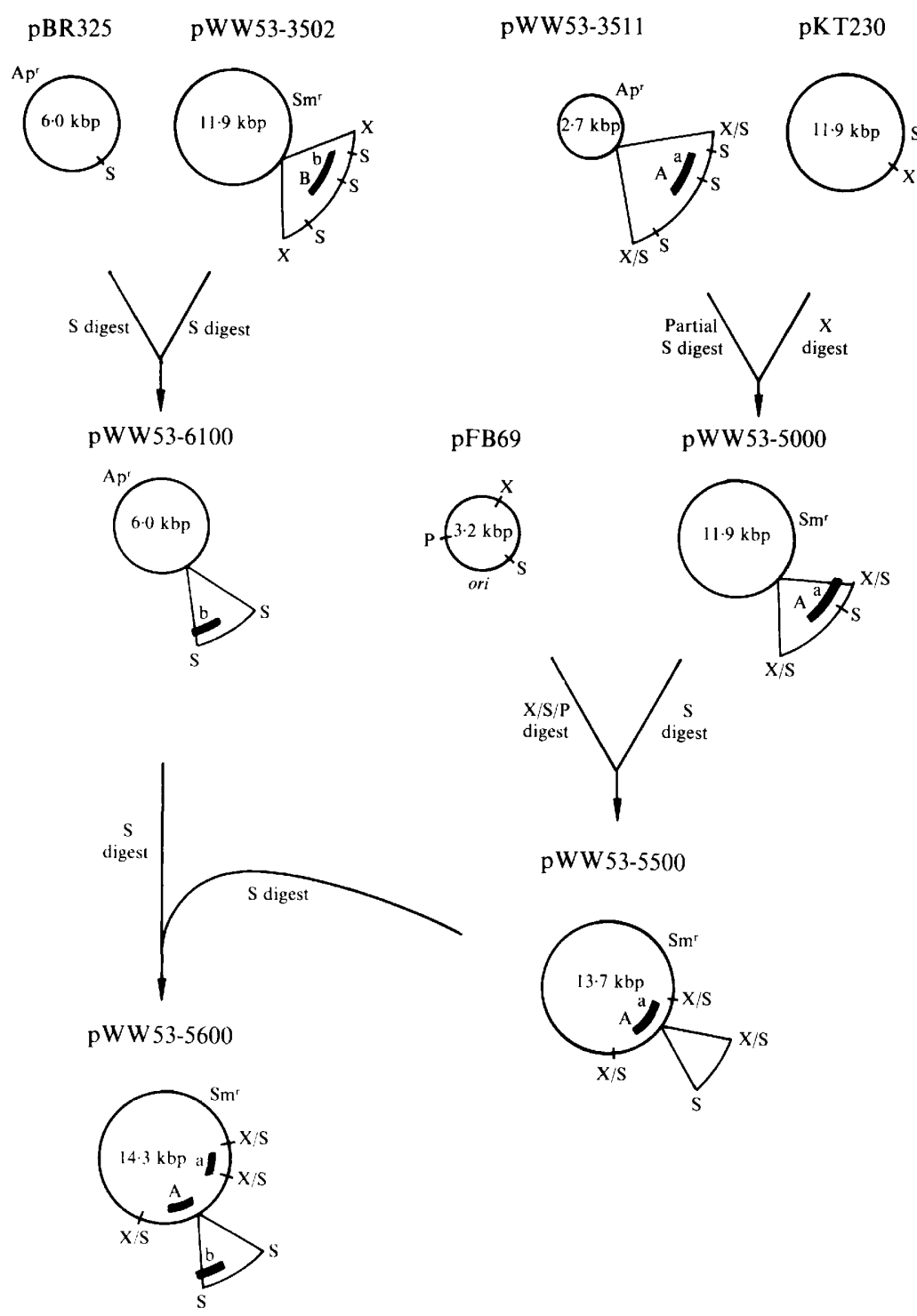

Fig. 2. Formation of a plasmid carrying a hybrid $x y l E$ gene of type $\mathrm{Ab}$. The relevant abbreviations for restriction enzymes are as in Fig. 1. The sizes of the plasmid circles (without their shown insert) are indicated inside the circles. The location of the $x y l$ genes and domains thereof are shown beside the DNA in a bold line. Relevant plasmid genes are shown in their rough location: $\mathrm{Ap}^{\mathrm{r}}$, ampicillin resistance: $\mathrm{Sm}^{r}$, streptomycin resistance; ori, replicative origin. The maps are not drawn to scale: for accurate sizes of the relevant DNA fragments see Fig. 1. enzymes ( $\mathrm{Bb}$ and $\mathrm{Ba}$ ) showed no such effect with catechol or with 4-methylcatechol and showed a marginal effect with 3-methylcatechol (see Fig. 3b). If high concentrations of 3-methylcatechol are inhibitory with these enzymes, then the effect is much weaker than with the $\mathrm{Aa}$ and $\mathrm{Ab}$ proteins. Since the common element of the two enzymes which show this effect is the N-terminal domain from the Aa protein, these results suggest that it is this region which is responsible for this effect, presumably because of its capacity for secondary substrate binding.

Because of this substrate inhibition, only the seven or eight values where $[S] \leqslant 0.5 \mathrm{~mm}$ were used to determine $K_{\mathrm{m}}$ and $V$. The values quoted in Table 2 are derived from five or six separate determinations using fresh cell extracts on each occasion.
The results are presented in graphical form in Fig. 4. Comparison of the $K_{\mathrm{m}}$ values for the three substrates and the four enzymes shows that the specificity profiles of the $\mathrm{Aa}$ and the Ba enzymes are similar, with highest $K_{\mathrm{m}}$ values for catechol, whereas the $\mathrm{Bb}$ and the $\mathrm{Ab}$ enzymes have a different profile with highest $K_{\mathrm{m}}$ values for 4methylcatechol (Fig. $4 a$ ). If the $K_{\mathrm{m}}$ is taken as a measure of the affinity of the protein for the substrate, this would lead to the conclusion that the site on the proteins determining their substrate affinity is located on their Cterminal halves, and that the ' $a$ ' domain had a weak affinity for catechol and the 'b' domain a weak affinity for 4-methylcatechol.

The values of $V$ are a measure of the catalytic activity of the extracts. Differences in the values could be the result of differences either in the intrinsic activity of 
$(a)$
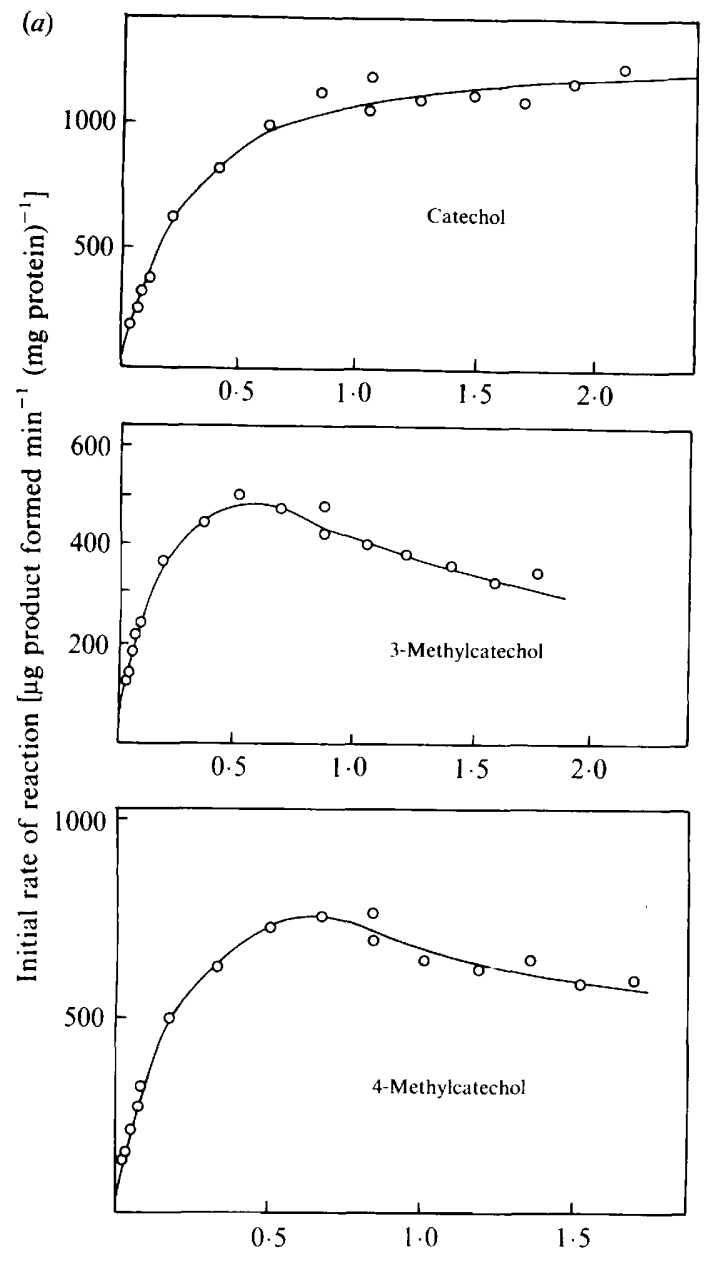

$[\mathrm{S}](\mathrm{mM})$
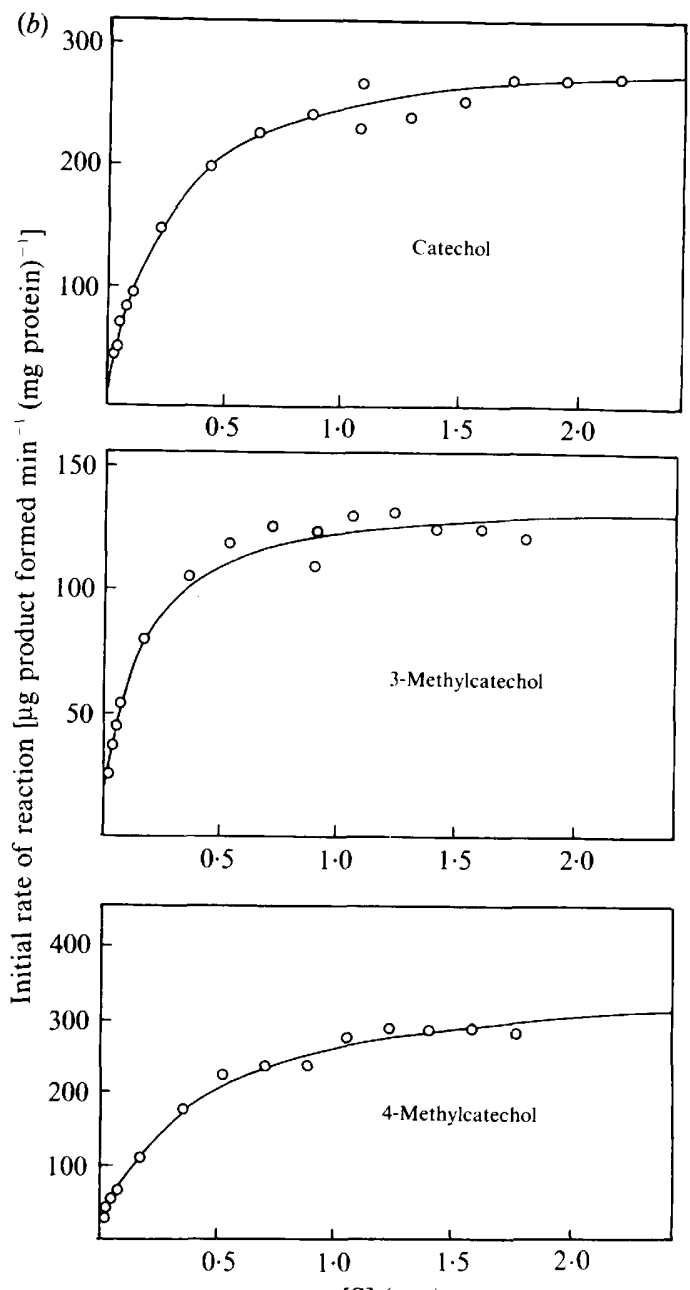

$[\mathrm{S}](\mathrm{mm})$

Fig. 3. Typical Michaelis-Menten curves for wild-type C23Os acting on catechol and the methylcatechols: $(a)$ enzyme of type Aa; $(b)$ enzyme of type $\mathrm{Bb}$. The curves for enzyme of type $\mathrm{Ab}$ are similar to those for $\mathrm{Aa}$, as are those for type $\mathrm{Ba}$ to type $\mathrm{Bb}$.

the two gene products or in the levels of transcription from the vector promoters due to the different intervening DNA in the recombinant plasmids. In the plasmids pWW53-3501 and pWW53-5600, this intervening DNA is not identical but differs by the deletion of a $0.23 \mathrm{kbp}$ $X$ XoI-SalI fragment in the latter (cf. Figs $1 a$ and $1 c$ ). It is possible, but unlikely, that the level of transcription is depressed in the latter as a direct result of a deletion bringing the promoter closer to the structural gene. It is more likely that any significant difference in $V$ is the result of a difference in the intrinsic catalytic activity of the gene product. The same argument can be applied to pWW53-3502 and pWW53-6600 (Figs $1 b$ and $1 d$ ). The values of $V$ therefore show that the introduction of the $C$ terminal end of the wild-type $\mathrm{Bb}$ protein reduces the catalytic activity of the Aa protein. Conversely the introduction of the C-terminus of the Aa protein into the $\mathrm{Bb}$ protein does not enhance its activity significantly. Thus either half of the $\mathrm{Bb}$ protein depresses the $V$, which we assume to be due to its intrinsically lower catalytic potential. Although not as clearly as in the case of the $K_{\mathrm{m}}$ values comparison of the specificity profiles for $V$ (Fig. $4 b$ ) suggests some linkage between the domains and the catalytic specificity. In fact the substrate profiles for both $K_{\mathrm{m}}$ and $V$ for all the enzymes look very similar (Fig. $4 a$, $b$ ), with a relatively high $K_{\mathrm{m}}$ matched by a high $V$. Thus for example the Aa protein appears to bind catechol less strongly than the methylcatechols (high $K_{\mathrm{m}}$ ) but catalyses its breakdown more effectively (high $V$ ). This is mirrored, but at lower levels, by the $\mathrm{Ba}$ protein, suggesting that the catalytic determinants are also concentrated in the $\mathrm{C}$-terminal regions. The compensa- 

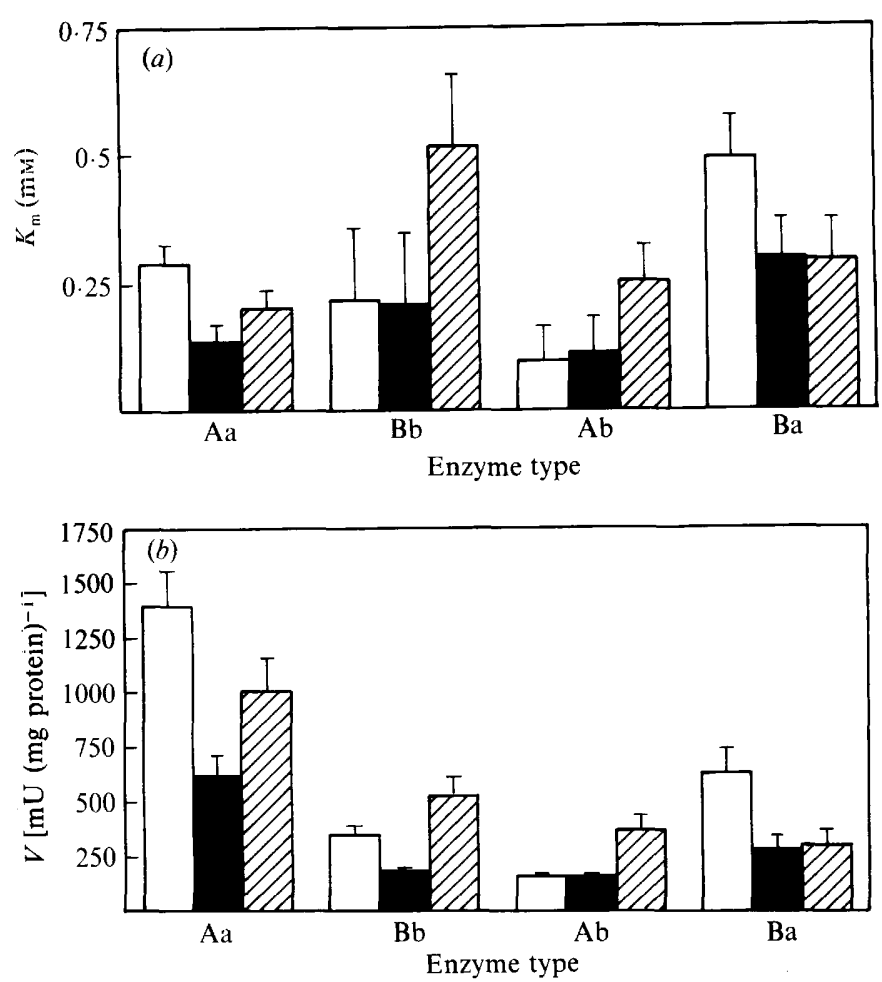

Fig. 4. Kinetic parameters calculated for wild-type and constructed hybrid C23Os plotted from Table 2. (a) Michaelis constant $\left(K_{\mathrm{m}}\right)$ values; (b) maximum velocity ( $V$ ) values. $\square$, Catechol; $\square$, 3-methylcatechol; 叉, 4-methylcatechol. tory effect of high $K_{\mathrm{m}}$ and high $V$ can be seen when the 'specificity constants' $\left(V / K_{\mathrm{m}}\right)$ are compared for all four proteins (Table 2). Although the values differ significantly between Aa and the other enzymes (reflecting its greater catalytic effectiveness), the values for the three substrates for each protein are roughly the same.

In previous papers the substrate specificities of catechol 2,3-oxygenases have been compared using the reaction rates determined in the standard assay procedure (see Keil et al., 1985). The kinetic analysis shows clearly that this can be a flawed procedure. The concentrations of substrates used in the assay $(\simeq 0.1 \mathrm{mM}$; Sala-Trepat \& Evans, 1971) are in most cases below the $K_{\mathrm{m}}$ value, and therefore the measured velocities do not approach the $V$ values: ideally the concentrations should be $\geqslant 5 \times K_{\mathrm{m}}$. As a result of this investigation we have increased the concentration of catechols in our standard assay procedure to $1 \mathrm{~mm}$. However this also has its dangers because of the possibility of substrate inhibition at this higher concentration. The only certain procedure to assess substrate specificities is to analyse the kinetics over a range of substrate concentrations and determine the kinetic parameters.

The position of the SalI site at which the fusion of the two genes has been effected has not yet been determined by DNA sequencing, but the $x y l E$ gene from $\mathrm{pWW} 0$ has been sequenced (Nakai et al., 1983) and this has a configuration of restriction sites very similar, but not

Table 2. Kinetic parameters for wild-type and hybrid catechol 2,3-oxygenases

$K_{\mathrm{m}}$ measured in mM: $V$ measured in milliunits (mg protein) $)^{-1}$. Values quoted are the mean \pm SD for five or six independent determinations with fresh cell extracts.

\begin{tabular}{|c|c|c|c|c|}
\hline \multirow{2}{*}{$\begin{array}{l}\text { Enzyme } \\
\text { type }\end{array}$} & \multirow[b]{2}{*}{ Parameter } & \multicolumn{3}{|c|}{ Substrate } \\
\hline & & Catechol & 3-Methylcatechol & 4-Methylcatechol \\
\hline Aa & $\begin{array}{l}K_{\mathrm{m}} \\
V \\
V / K_{\mathrm{m}} \\
\text { Substrate } \\
\text { inhibition }\end{array}$ & $\begin{array}{c}0.290 \pm 0 \cdot 040 \\
1400 \pm 160 \\
4800\end{array}$ & $\begin{array}{c}0 \cdot 135 \pm 0 \cdot 021 \\
620 \pm 100 \\
4600 \\
+\end{array}$ & $\begin{array}{c}0.201 \pm 0 \cdot 036 \\
1010 \pm 150 \\
5000 \\
+\end{array}$ \\
\hline $\mathbf{B b}$ & $\begin{array}{l}K_{\mathrm{m}} \\
V \\
V / K_{\mathrm{m}} \\
\text { Substrate } \\
\text { inhibition }\end{array}$ & $\begin{array}{c}0.218 \pm 0.036 \\
350 \pm 40 \\
1600\end{array}$ & $\begin{array}{c}0.208 \pm 0 \cdot 034 \\
185 \pm 16 \\
890\end{array}$ & $\begin{array}{c}0 \cdot 518 \pm 0 \cdot 14 \\
530 \pm 80 \\
1000\end{array}$ \\
\hline $\mathrm{Ab}$ & $\begin{array}{l}K_{\mathrm{m}} \\
V \\
V / K_{\mathrm{m}} \\
\text { Substrate } \\
\text { inhibition }\end{array}$ & $\begin{array}{c}0.095 \pm 0 \cdot 015 \\
161 \pm 11 \\
1700\end{array}$ & $\begin{array}{c}0 \cdot 113 \pm 0 \cdot 020 \\
157 \pm 12 \\
1400\end{array}$ & $\begin{array}{c}0.252 \pm 0 \cdot 069 \\
380 \pm 60 \\
1500\end{array}$ \\
\hline $\mathrm{Ba}$ & $\begin{array}{l}K_{\mathrm{m}} \\
V \\
V / K_{\mathrm{m}} \\
\text { Substrate } \\
\text { inhibition }\end{array}$ & $\begin{array}{c}0.494 \pm 0.036 \\
640 \pm 110 \\
1300\end{array}$ & $\begin{array}{c}0.297 \pm 0.058 \\
280 \pm 60 \\
930\end{array}$ & $\begin{array}{c}0.294 \pm 0 \cdot 078 \\
300 \pm 80 \\
1000\end{array}$ \\
\hline
\end{tabular}


identical, to the Aa gene (see Chatfield \& Williams, 1986). In the pWW0 gene the Sall site spans bases 579584 , coding for amino acids Leu-Ser-Thr (193-195) in the sequence of 306 amino acid residues. Assuming that the $\mathrm{SalI}$ site is in the same location in the $\mathrm{Aa}$ and $\mathrm{Bb}$ genes, the $\mathrm{N}$-terminal region covers the first 194 residues and the C-terminal region the final 112 residues.

The method used in this paper of constructing in vitro hybrids between homologous genes clearly has limitations in its general applicability as a method of assigning functions to relevant regions of their gene products. Not the least of these is whether particular biochemical properties of a protein (catalysis, binding, $\mathrm{pH}$ variations, subunit association, etc.) can be definitively assigned to a unique region of the linear sequence. However, within these limitations of interpretation, the results presented here indicate that: $(a)$ the two $\mathrm{C} 23 \mathrm{O}$ enzymes from pWW53 differ significantly in their intrinsic catalytic activity against all three substrates tested; $(b)$ the Cterminal region of each appears to be dominant in determining their substrate specificity, with regard to both binding strength and catalysis, which would further suggest that the main active-site amino acids were located in this region; $(c)$ the $\mathrm{N}$-terminal region of the $\mathrm{Aa}$ protein carries a site which makes the enzyme susceptible to inhibition by excess concentrations of the two methylcatechols.

\section{References}

Bagdasarian, M., Lurz, R., Rückert, B., Franklin, F. C. H., Bagdasarian, M. M., Frey, J. \& Timmis, K. N. (1981). Specific purpose plasmid cloning vectors. II. Broad host range, high copy number RSF1010-derived vectors and a host : vector system for gene cloning. Gene 16, 237-247.

BARANY, F. (1985). Two-codon insertion mutagenesis of plasmid genes by using single stranded hexameric oligonucleotides. Proceedings of the National Academy of Sciences of the United States of America 82, $4202-4206$

CANE, P. A. \& Williams, P. A. (1982). The plasmid-coded metabolism of naphthalene and 2-methylnaphthalene in Pseudomonas strains: phenotypic changes correlated with structural modification of the plasmid pWW60-1. Journal of General Microbiology 128, 2281-2290.

ChatField, L. K. \& Williams, P. A. (1986). Naturally-occurring TOL plasmids isolated from soil carry either two homologous or two nonhomologous catechol 2,3-oxygenase genes. Journal of Bacteriology 168, 878-885.

Keil, H., Lebens, M. R. \& Williams, P. A. (1985). TOL plasmid pWW 15 contains two non-homologous, independently regulated catechol 2,3-oxygenase genes. Journal of Bacteriology 163, 248-255.

Nakai, C., Kagamiyama, H., Nozaki, M., Inouye, S., Ebina, Y. \& NaKaZawa, A. (1983). Complete nucleotide sequence of the metapyrocatechase gene on the TOL plasmid of Pseudomonas putida mt-2. Journal of Biological Chemistry 258, 2923-2928.

Osborne, D. J., Pickup, R. W. \& Williams, P. A. (1988). The presence of two homologous meta pathway operons on TOL plasmid pWW53. Journal of General Microbiology 134, 2965-2975.

PRENTKI, P. \& KIRSCH, A. M. (1982). A modified pBR322 vector with improved properties for the cloning, recovery and sequencing of blunt-ended DNA fragments. Gene 17, 189-196.

Sala-Trepat, J-M. \& Evans, W. C. (1971). The meta cleavage of catechol by Azotobacter species: 4-oxalocrotonate pathway. European Journal of Biochemistry 20, 400-413.

WILKINSON, G. N. (1961). Statistical estimations in enzyme kinetics. Biochemical Journal 80, 324-332.

Williams, P. A. \& Zaba, B. N. (1989) enzPack3. Cambridge, UK: Biosoft.

Yanisch-Perron, C., Vieira, J. \& Messing, J. (1985). Improved M13 phage cloning vectors and host strains: nucleotide sequences of the M13mp18 and PUC19 vectors. Gene 33, 103-119. 